\title{
Chitinase B from Serratia marcescens BJL200 is exported to the periplasm without processing
}

\author{
May B. Brurberg, ${ }^{1,2}$ Vincent G. H. Eijsink, ${ }^{1}$ Alfred J. Haandrikman, ${ }^{3}$ \\ Gerard Venema ${ }^{3}$ and Ingolf F. Nes ${ }^{1}$
}

Author for correspondence: May B. Brurberg. Tel: + 4764949461 . Fax: +4764941465.
e-mail: mbruberg@bioslave.uio.no

1 Laboratory of Microbial Gene Technology,

Agricultural University of Norway, PO Box 5051,

1432 Ås, Norway

2 The Norwegian State Agricultural Research Stations, Ås, Norway

3 Department of Genetics, Centre of Biological Sciences, University of Groningen, The Netherlands

\begin{abstract}
A gene encoding a chitinase from Serratia marcescens BJL200 was cloned and expressed in Escherichia coli and S. marcescens. Nucleotide sequencing revealed an open reading frame encoding a $55.5 \mathrm{kDa}$ protein of 499 amino acids without a typical signal peptide for export. The cellular localization of the chitinase was studied, using two types of cell fractionation methods and immunocytochemical techniques. These analyses showed that the chitinase is located in the cytoplasm in E. coli, whereas it is exported to the periplasm in S. marcescens. Analysis of chitinase isolated from periplasmic fractions of $S$. marcescens carrying the cloned gene showed that export of the enzyme is not accompanied by processing at the $\mathrm{N}$-terminus. The chitinase did not show any of the characteristics that have been proposed to direct the export of other non-processed extracellular proteins such as the $E$. coli haemolysin and might therefore be secreted via a hitherto unknown mechanism.
\end{abstract}

Keywords: Serratia marcescens, chitinase, export, signal peptide

\section{INTRODUCTION}

Several bacteria and fungi are capable of enzymic degradation of chitin, the $(1 \rightarrow 4)$ - $\beta$-linked polymer of $N$-acetyl$\beta$-D-glucosamine (GlcNAc), for autolytic, morphogenetic or nutritional purposes (Gooday, 1990). The chitinolytic enzyme system is composed of chitinases (EC 3.2.1.14), chitobiosidases (Tronsmo \& Harman, 1993) and $N$ acetyl- $\beta$-glucosaminidases (EC 3.2.1.52). Chitinases cleave glycosidic linkages randomly along the chitin chain, eventually giving $N, N^{\prime}$-diacetyl- $\beta$-D-chitobiose $\left[(\mathrm{GlcNAc})_{2}\right]$ as endproduct (Monreal \& Reese, 1969), while chitobiosidases cleave off (GlcNAc) ${ }_{2}$ units from the non-reducing end of the polysaccharide chain (Tronsmo \& Harman, 1993). The dimer (GlcNAc) ${ }_{2}$ is further hydrolysed to GlcNAc residues by $N$-acetyl- $\beta$-glucosaminidase (Monreal \& Reese, 1969).

Serratia marcescens, a Gram-negative bacterium belonging to the family Enterobacteriaceae, is one of the most efficient bacteria for degradation of chitin (Monreal \& Reese, 1969; Schickler et al., 1993). Production of chitinolytic enzymes in $S$. marcescens is induced by the presence of chitin in the culture medium (Monreal \& Reese, 1969).

Abbreviation: 4-MU-(GICNAC), 4-methylumbelliferyl- $\beta$-D- $N, N^{\prime}$-diacetylchitobioside.

The EMBL accession number for the sequence reported in this paper is Z36295.
Fuchs et al. (1986) showed that $S$. marcescens strain QMB1466 produced five different chitinolytic enzymes upon induction with chitin. Two chitinase genes (cbi $A$ and $c b i B$ ) have been isolated from this organism and their nucleotide sequences have been determined (Jones $e t$ al., 1986; Harpster \& Dunsmuir, 1989). A chromosomal fragment encoding a $95 \mathrm{kDa} N$-acetyl- $\beta$-glucosaminidase was isolated and characterized by Kless et al. (1989); however, no sequence was reported for this enzyme. Sundheim et al. (1988) cloned two chromosomal fragments encoding chitinolytic activity from $S$. marcescens BJL200. In the present study we have analysed one of these fragments and determined the nucleotide sequence of the chitinase gene located on it.

Previous studies of $S$. marcescens chitinases have in most cases not clearly revealed the cellular location of the enzymes and possible export mechanisms. Chitinolytic enzymes are normally found in the culture medium, suggesting that they are secreted. However, the chitinolytic enzymes were isolated from the culture medium after prolonged culturing times (6-8 d) (Monreal \& Reese, 1969; Roberts \& Cabib, 1982; Fuchs et al., 1986; Jones et al., 1986). Conceivably the presence of these enzymes in the culture medium may have occurred as a result of cell lysis. Generally, the translocation of bacterial proteins across the cytoplasmic membrane is directed by an $\mathrm{N}$ terminal signal peptide which is removed during or shortly after the translocation step. In Gram-negative 
bacteria, an additional step is required to transport the protein across the outer membrane. Alternatively the two membranes are crossed in a single step. The latter mechanism involves proteins which lack a typical $\mathrm{N}$ terminal signal peptide, and which are not processed during translocation (reviewed by Lory, 1992; Wandersman, 1992; Pugsley, 1993). In the present study we used cell fractionation and immunocytochemical methods to study the location of the cloned $S$. marcescens BJL200 chitinase in E. coli and S. marcescens. These studies provide unequivocal evidence that the chitinase is exported to the periplasm in $S$. marcescens without the help of a signal peptide and without any processing.

\section{METHODS}

Bacterial strains and culture conditions. Eschericbia coli $\mathrm{DH} 1$ and $\mathrm{DH} 5 \alpha$ (Hanahan, 1983) were grown at $37^{\circ} \mathrm{C}$ in Luria Broth (LB). Serratia marcescens BJL200 (Sundheim et al., 1988) was grown at $30^{\circ} \mathrm{C}$ in LB. For plates, LB was solidified with $1.5 \%$ (w/v) agar. Ampicillin was added at the following final concentrations : $50 \mu \mathrm{g} \mathrm{ml}^{-1}$ for $E$. coli and $300 \mu \mathrm{g} \mathrm{ml}^{-1}$ for $S$. marcescens.

Enzymes. DNA-modifying enzymes were obtained from New England Biolabs and were used with buffers and protocols supplied with the enzymes.

DNA techniques. Recombinant DNA work was done by using standard protocols (Sambrook et al., 1989). All fragments for cloning were separated by agarose gel electrophoresis and purified with Geneclean (BIO101). Transformation of E. coli and $S$. marcescens was carried out by electroporation according to the protocol of Dower et al. (1988), using a Bio-Rad Gene Pulser.

Deletion plasmids and subclones. pLES3-1, pLES3-2 and pLES3-3 (Fig. 1) were constructed by deleting a MluI, SacI and HpaI fragment, respectively, from pLES3 (Fig. 1). pMAY1 (Fig. 1) was constructed by recloning the $2 \cdot 3 \mathrm{~kb}$ EcoRI-SacI fragment in pGEM-7f( +$) Z$ (Promega) digested with the same enzymes. pMAY2-10 (Fig. 1) was constructed by cutting pLES3 with $M l u \mathrm{I}$, filling in the $3^{\prime}$ recessed termini with Klenow fragment of DNA polymerase I, digesting with EcoRI and tecloning the $1.8 \mathrm{~kb}$ EcoRI-MluI fragment in pGEM-7f(+)Z cut with EcoRI and SmaI.
DNA sequence analysis. A $1.8 \mathrm{~kb}$ XbaI-HindIII fragment from pMAY2-10 (Fig. 1) was subcloned into vector M13mp18 and M13mp19 (Yanisch-Perron et al., 1985) cut with the same enzymes. The nucleotide sequence was obtained by sequencing single-stranded DNA by the dideoxy chain-termination method (Sanger et al., 1977) using the Sequenase DNA sequencing kit (United States Biochemical) and $\left[{ }^{35} \mathrm{~S}\right] \mathrm{dATP}-\alpha \mathrm{S}$ (Amersham). The DNA sequence was determined starting from the universal primer, and additional primers were designed with the newly obtained sequence information using a walking strategy. Synthetic oligonucleotide primers were synthesized on an Applied Biosystems 380/381 DNA synthesizer. Ambiguous sequences due to band compression were resolved by running formamide gels $(40 \%, v / v)$ as described by the supplier of the sequencing chemicals [USB Comments 17(1), 1990]. Computerassisted sequence analysis was performed using PCGENE microcomputer software (IntelliGenetics). Searches for nucleotide and amino acid sequence similarities were done with the FASTA program (Pearson \& Lipman, 1988) in the EMBL and SwissProt databases. Comparison of protein sequences was performed using the computer programs COMPARE, BESTFIT, and PILEUP of the University of Wisconsin Genetics Computer Group.

Fractionation of $\boldsymbol{E}$. coli and $\boldsymbol{S}$. marcescens cells. Cells were harvested in the exponential growth phase $\left(\mathrm{OD}_{600} \sim 0.7\right)$ and the supernatant saved as the extracellular fraction. Because some cytoplasmic proteins are released into the periplasmic fraction by an osmotic shock (teviewed by Oliver, 1987), two methods were used for the preparation of periplasmic fractions. In method A the periplasmic fraction was prepared by osmotic shock (Manoil \& Beckwith, 1986). In method B the periplasmic fraction was prepared by converting the cells to spheroplasts by the action of lysozyme and EDTA (Koshland \& Botstein, 1980). Cytoplasmic fractions were obtained by disrupting with glass beads the cell pellet remaining after osmotic shocking or lysozyme treatment, as described by van de Guchte et al. (1990).

Determination of protein concentration. Protein concentrations were determined by the method of Bradford (1976), with bovine serum albumin as a standard.

\section{Assays for detection of chitinolytic activity}

(i) Plate assay. Chitinolytic activity was initially scored by the ability of a bacterial colony to produce a halo of clearing on a chitin containing agar plate, prepared by overlaying a $15 \mathrm{ml} \mathrm{M} 9$ (minimal salts, Gibco) agar base with $10 \mathrm{ml} 1.5 \%(\mathrm{w} / \mathrm{v}$ ) agar and $1.5 \%(\mathrm{w} / \mathrm{v})$ colloidal chitin (Vessey \& Pegg, 1973).

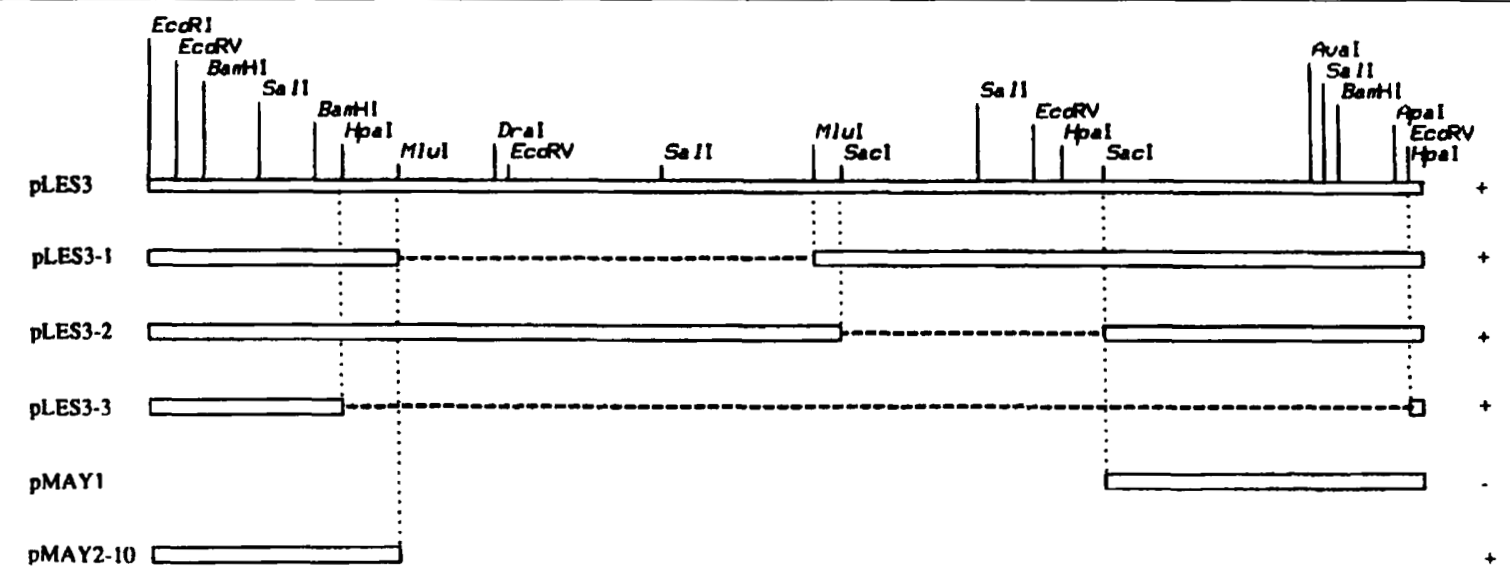

Fig. 1. Schematic representation of the $9.2 \mathrm{~kb}$ chitinase-coding ECoRI fragment isolated from S. marcescens BJL200, and the deletion clones constructed from this fragment. Chromosomal DNA is indicated by open boxes, and deletions are indicated by broken lines. Chitinolytic activity, as scored by the plate assay, is indicated by + on the right. 
(ii) Cleavage of 4-methylumbelliferyl- $\beta$-D- $N, N^{\prime}$-diacetylchitobioside [4-MU-(GICNAC) ], a chitin trimer analogue. Cell-free extracts were tested for chitinolytic activity against 4-MU-(GlcNAc) ${ }_{2}$ (Sigma) (Kuranda \& Robbins, 1987). The standard reaction mixture contained $70 \mu \mathrm{M} 4-\mathrm{MU}-(\mathrm{GlcNAc})_{2}$ in $50 \mathrm{mM}$ citrate phosphate buffer, $\mathrm{pH} 6.0$ (total volume of $50 \mu \mathrm{l}$ ). The reaction mixture was incubated at $37^{\circ} \mathrm{C}$, and after $10 \mathrm{~min}$ the reaction was stopped by adding $1.95 \mathrm{ml} 0.2 \mathrm{M} \mathrm{Na}_{2} \mathrm{CO}_{3}$. The 4-methylumbelliferone (4MU) moiety is fluorescent when it becomes ionized above $\mathrm{pH} 8$ and after excitation at $380 \mathrm{~nm}$, it emits at a wavelength of $460 \mathrm{~nm}$. The amount of 4-MU released was determined with a TKO 100 Mini Fluorimeter (Hoefer Scientific Instruments). Chitinolytic activity is given in $\mathrm{nmol} 4-\mathrm{MU}$ released $\mathrm{min}^{-1}(\mathrm{ml}$ culture) $)^{-1}$.

(iii) Detection of chitinolytic activity after SDS-PAGE. SDS-PAGE $(10 \%, \mathrm{w} / \mathrm{v}$, polyacrylamide gel) was performed using a BioRad Protean II minigel system essentially according to the method of Laemmli (1970), but modified with addition of $0.01 \%$ glycol chitin to the running gel (Trudel \& Asselin, 1989). After electrophoresis, the gel was incubated for $3 \times 20 \mathrm{~min}$ in $1 \%(\mathrm{v} / \mathrm{v})$ Triton $\mathrm{X}-100,25 \mathrm{mM}$ Tris buffer ( $\mathrm{pH} 7.5$ ), $20 \mathrm{mM} \mathrm{MgCl}$ at room temperature, followed by overnight incubation in $0.1 \%$ Triton X-100, $25 \mathrm{mM}$ Tris buffer ( $\mathrm{pH} \mathrm{7.5),} 20 \mathrm{mM} \mathrm{MgCl}$, to allow renaturation of proteins. The gel was then washed in $100 \mathrm{mM}$ phosphate buffer $(\mathrm{pH} \mathrm{6})$ for $3 \times 20 \mathrm{~min}$, stained with Calcofluor White M2R (Sigma), destained and visualized by UV illumination, as described by Trudel \& Asselin (1989). Proteins with chitinolytic activity appeared as dark bands on a fluorescent background.

$\boldsymbol{\beta}$-Galactosidase assay. $\boldsymbol{\beta}$-Galactosidase activity was measured in the fractions of $E$. coli DH1 by the method of Miller (1972) and expressed as nmol o-nitrophenol released $\min ^{-1}(\mathrm{ml}$ culture $)^{-1}$.

Aldolase assay. Aldolase activity in the fractions of $S$. marcescens was measured using the aldolase assay kit from Boehringer Mannheim according to the manufacturer's recommendations, except that the reaction was carried out at $20^{\circ} \mathrm{C}$. Activity is expressed as nmol NADH converted $\min ^{-1}$ (ml culture) ${ }^{-1}$.

Amino acid sequencing. The chitinase was purified from a periplasmic fraction of $S$. marcescens BJL200(pMAY2-10) obtained by osmotic shocking, according to the protocol of Brurberg et al. (1994). The amino acid sequence was determined by Edman degradation using an automatic sequenator (model 477A, Applied Biosystems).

Antibody preparation and immunocytochemical analysis. A rabbit was injected subcutaneously three times at monthly intervals with mashed SDS-polyacrylamide gel slices containing approximately $20 \mu \mathrm{g}$ chitinase from the periplasmic fraction of E. coli DH1(pMAY2-10). The first injection was given with $50 \%(\mathrm{v} / \mathrm{v})$ Freund's complete adjuvant, whereas the second and third injections were given with $50 \%$ Freund's incomplete adjuvant. Sera were collected after the third injection. Ultrathin sections of $S$. marcescens cells were prepared and immunogold labelled as described elsewhere (Haandrikman et al., 1991).

\section{RESULTS}

\section{Subcloning of a $9.2 \mathrm{~kb}$ fragment carrying a chitinase determinant}

pLES3, consisting of a $9 \cdot 2 \mathrm{~kb}$ EcoRI chromosomal fragment from $S$. marcescens in pBR325, was previously shown to confer chitinase activity upon $E$. coli (Sundheim et al., 1988). To localize the region encoding the chitino-
Table 1. Chitinolytic activity in S. marcescens and E. coli strains

The chitinase activity was measured in periplasmic fractions obtained by osmotic shocking. Values are the means of three independent experiments. Standard deviations were less than $10 \%$ of the means.

\begin{tabular}{|lc|}
\hline Strain & $\begin{array}{c}\text { Activity } \\
\text { [nmol } \text { min }^{-1} \\
\text { (ml culture) }^{-1} \text { ] }\end{array}$ \\
\hline E. coli DH1 & 0 \\
E. coli $\mathrm{DH} 1$ (pGEM-7f(+)Z) & 0 \\
E. coli $\mathrm{DH} 1$ (pMAY2-10) & 17 \\
S. marcescens BJL200 & $0 \cdot 5$ \\
S. marcescens BJL200(pMAY2-10) & 11 \\
\hline
\end{tabular}

(a)

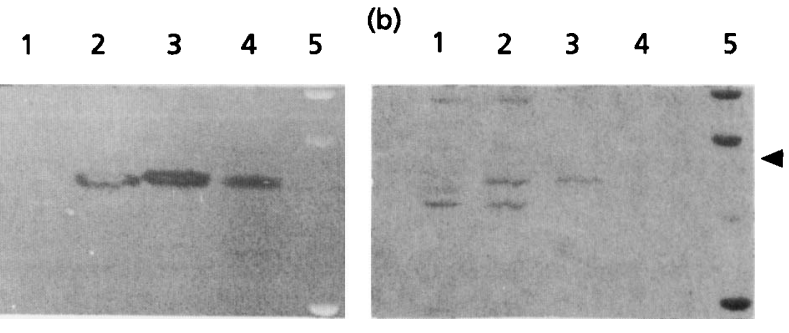

Fig. 2. Chitinolytic activity after SDS-PAGE in a gel containing $0.01 \%(w / v)$ glycol chitin. Periplasmic fractions obtained by osmotic shocking of $E$. coli DH1(pGEM-7f(+)Z) (lane 1); $E$. coli DH1(pMAY2-10) (lane 2); S. marcescens BJL200(pMAY2-10) (lane 3); S. marcescens BJL200 (lane 4). Lane 5 contains molecular mass markers (kDa): phosphorylase $b(94)$, albumin (67), ovalbumin (43) and carbonic anhydrase (30). (a) Gel stained with Calcofluor White. Chitinolytic proteins appear as dark bands (lytic zones) during UV illumination. (b) Protein staining with Coomassie Brilliant Blue G-250. The arrowhead indicates the $55 \mathrm{kDa}$ chitinolytic protein.

lytic activity, several deletion derivatives of pLES3 were made (Fig. 1). The deletion derivatives were introduced into $E$. coli, and the resulting transformants were screened for chitinolytic activity by plate assay. The results indicated that the chitinolytic activity of pLES3 was located on a $1.4 \mathrm{~kb}$ EcoRI-HpaI fragment (Fig. 1). A slightly larger fragment $(1.8 \mathrm{~kb} E c o \mathrm{RI}-M l u \mathrm{I})$ was subcloned to the high-copy-number vector pGEM- $7 f(+) Z$ and the resulting plasmid was called pMAY2-10 (Fig. 1).

\section{Overexpression of the chitinase activity in $S$. marcescens}

Plasmid pMAY2-10 encoding the chitinase activity was introduced into the $S$. marcescens wild-type strain BJL200 by electroporation. The transformed $S$. marcescens showed a 20 -fold increase in chitinolytic activity compared to the wild-type, as measured by hydrolysis of 4-MU-(GlcNAc) ${ }_{2}$ (Table 1). Proteins produced by E. coli DH1(pMAY2-10), 


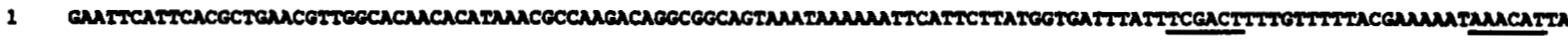

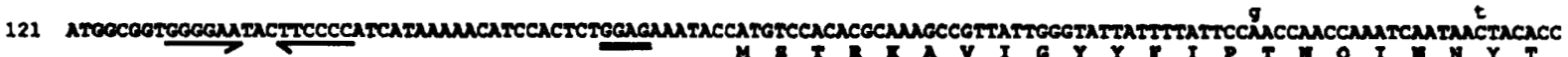

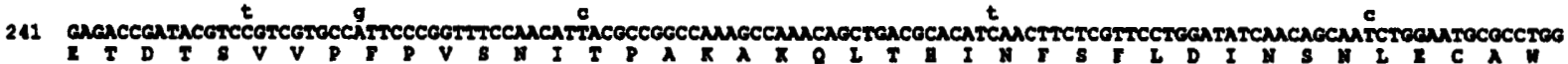

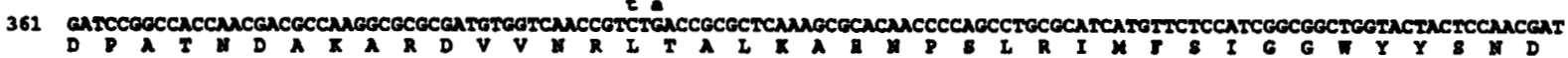

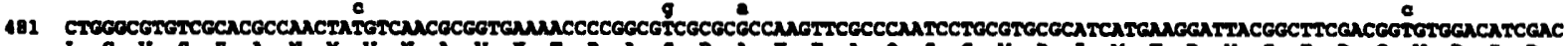

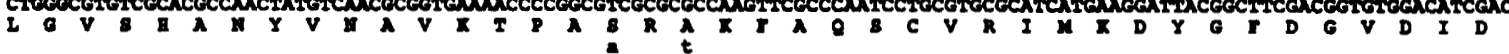

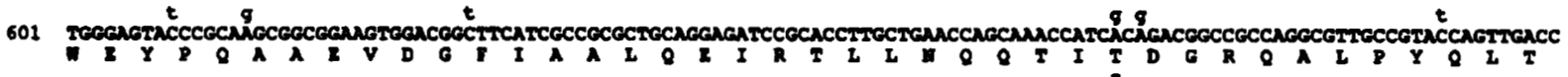

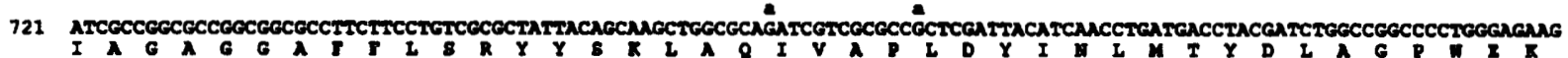

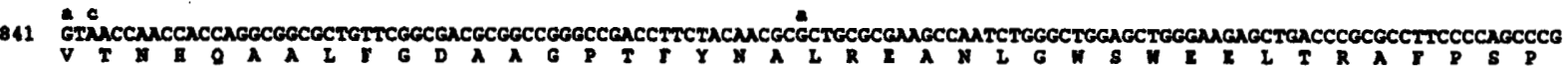

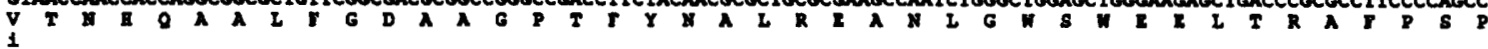

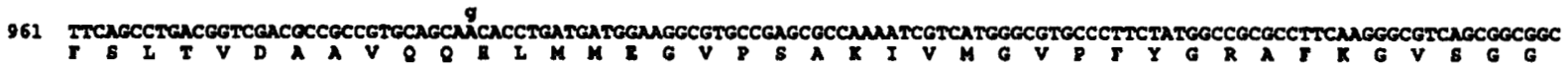

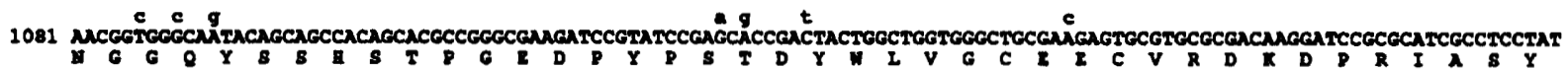

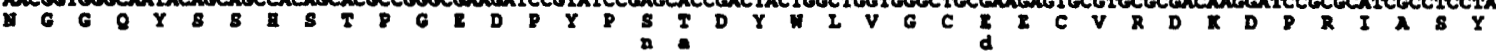

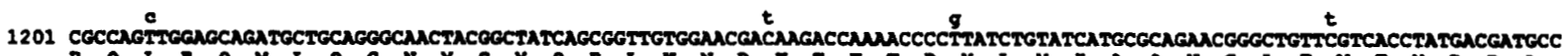

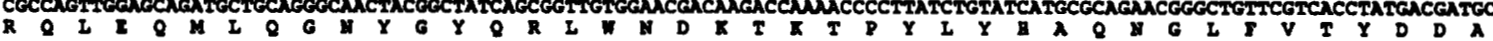

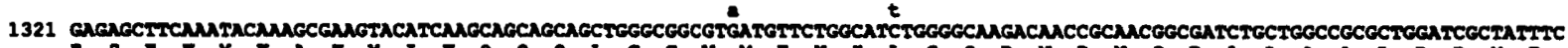

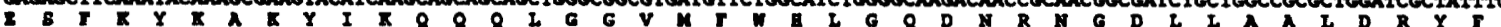

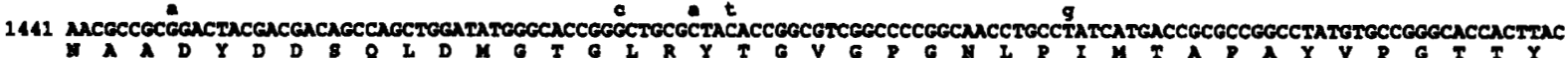

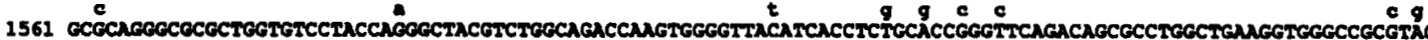

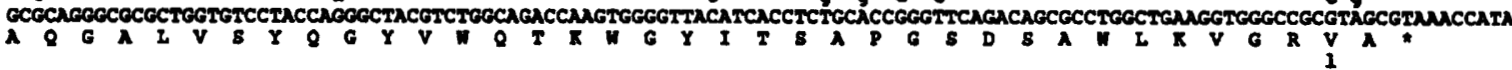

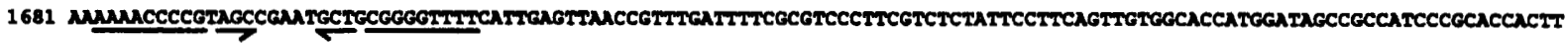

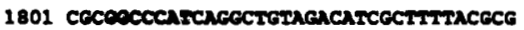

Fig. 3. Nucleotide sequence of the $1.8 \mathrm{~kb}$ EcoRI-Mlul chitinase-encoding restriction fragment from S. marcescens BJL200. The deduced amino acid sequence of the chitinase is shown below the nucleotide sequence. Differences in nucleotide and amino acid sequence from chiB isolated from S. marcescens QMB1466 (Harpster \& Dunsmuir, 1989) are indicated in lower-case type. A putative promoter -10 and -35 region is underlined. The ribosome-binding site is double underlined. The putative terminator eight bases downstream of the UAA stop codon (indicated with an asterisk) and a stem-loop structure 31 bases upstream of the ATG start codon are marked with inverted arrows.

S. marcescens BJL200 and S. marcescens BJL200(pMAY2-10) were analysed by SDS-PAGE, using gels containing glycol chitin as described in Methods. Fig. 2(a) shows that all three strains gave one distinct band with chitinolytic activity, which was absent in E. coli DH1 without pMAY2-10. Staining of the gels with Coomassie blue revealed a major $55 \mathrm{kDa}$ protein band at the position of the activity band (Fig. 2b), occurring only in strains containing pMAY2-10. The observation that a Coomassie-stained chitinase band was only present in $S$. marcescens BJL200(pMAY2-10), and not in strain BJL200 lacking this plasmid, demonstrates the higher expression level of the chitinase in the transformed strain.

\section{Nucleotide sequence analysis of the chitinase gene region}

The nucleotide sequence of the $1836 \mathrm{bp}$ EcoRI-MluI fragment encoding the chitinase gene was determined (Fig. 3). The sequence data revealed two long open reading frames (ORF1 and ORF2). ORF1 (151-1672) has an ATG start codon at position 175 which is preceded by 
Table 2. Cellular location of enzymic activities in E. coli DH1 (pMAY2-10) and S. marcescens BJL200(pMAY2-10)

Exponentially growing cells were fractionated by osmotic shocking (osm) or spheroplasting by lysozyme treatment (sph). Figures in the parentheses represent the percentage of the total activity in the culture. Values are the means of three independent experiments. Standard deviations were less than $10 \%$ of the means.

\begin{tabular}{|c|c|c|c|c|}
\hline \multirow[t]{3}{*}{ Cell fraction } & \multicolumn{4}{|c|}{ Enzyme activity $\left[\mathrm{nmol} \mathrm{min}^{-1}(\mathrm{ml} \text { culture })^{-1}\right.$ ] } \\
\hline & \multicolumn{2}{|c|}{ Chitinase } & \multicolumn{2}{|c|}{$\beta$-Galactosidase/aldolase* } \\
\hline & osm & sph & osm & sph \\
\hline \multicolumn{5}{|c|}{ E. coli DH1(pMAY2-10) } \\
\hline Extracellular & $0 \cdot 6(3)$ & $0.9(4)$ & $16(4)$ & $4(1)$ \\
\hline Periplasmic & $17(78)$ & $4 \cdot 6(20)$ & $60(15)$ & $81(19)$ \\
\hline Cytoplasmic & $4 \cdot 1(19)$ & $17 \cdot 6(76)$ & $322(81)$ & $340(80)$ \\
\hline \multicolumn{5}{|c|}{ S. marcescens BJL200(pMAY2-10) } \\
\hline Extracellular & $0.03(<1)$ & $0.02(<1)$ & $0 \cdot 3(<1)$ & $0.4(<1)$ \\
\hline Periplasmic & $11(77)$ & $10 \cdot 7(81)$ & $2.1(2)$ & $5(5)$ \\
\hline Cytoplasmic & $3 \cdot 3(23)$ & $2 \cdot 5(19)$ & $109(98)$ & $98(95)$ \\
\hline
\end{tabular}

* $\beta$-Galactosidase was used as a cytoplasmic marker for $E$. coli and aldolase was used as a cytoplasmic marker for $S$. marcescens.

a possible ribosome-binding site (Shine \& Dalgarno, 1974). It could encode a protein of 499 amino acids with a calculated molecular mass of $55469 \mathrm{Da}$. ORF2 (202$1690)$ is located on the opposite strand of ORF1 and shares triplets with ORF1. However, in ORF2 no correctly spaced combination of a Shine-Dalgarno sequence and a start codon (ATG or GTG) could be detected, suggesting that ORF1 is the frame encoding the chitinase activity. The calculated molecular mass $(55469 \mathrm{Da})$ of the protein encoded by ORF1 is in good agreement with the size of the protein with chitinolytic activity that was detected by SDS-PAGE (Fig. 2). The conclusion that ORF1 encodes the chitinase was confirmed by $\mathrm{N}$-terminal sequencing of the gene product (see below).

Computer analysis of the region upstream of the coding region revealed a putative prokaryotic promoter region (Fig. 3). Between this region and the ATG start codon a stable stem-loop structure $\left(\Delta G=-12 \mathrm{kcal} \mathrm{mol}^{-1}\right.$; $-50 \mathrm{~kJ} \mathrm{~mol}^{-\mathbf{1}}$ ), which could be part of a regulatory mechanism for the expression of the gene, was observed (Fig. 3). A typical tho-independent transcription termination signal (Carafa et al., 1990) with a free energy $(\Delta G)$ of $-18 \mathrm{kcal} \mathrm{mol}^{-1}\left(-75 \mathrm{~kJ} \mathrm{~mol}^{-1}\right)$ was identified 10 nucleotides downstream from the termination codon (Fig. 3).

The deduced amino acid sequence of the chitinase was compared to other known chitinase sequences. The chitinase in this study exhibited $98.4 \%$ identity with a chitinase encoded by the $c h i B$ gene of $S$. marcescens strain QMB1466 (Harpster \& Dunsmuir, 1989). Comparison of these proteins at the gene level revealed $96.4 \%$ identity in the coding regions and $95.8 \%$ identity when accessible upstream and downstream sequences were included in the comparison. Therefore, the chitinase gene cloned and characterized in this study will hereafter be referred to as cbiB.

\section{Location of chitinase $B$ in $E$. coli cells containing chiB}

As it took several days for $E$. coli harbouring any of the plasmids encoding chitinolytic activity (Fig. 1) to produce a clearing halo on a chitin-containing agar plate, we suspected that extracellular chitinolytic activity could be due to lysis of cells rather than to secretion of chitinolytic activity. To determine the cellular location of the chitinolytic activity, the E. coli DH1(pMAY2-10) cells were fractionated and the fractions were tested for chitinolytic activity against 4-MU-(GlcNAc) ${ }_{2}$ (Table 2). The two methods for cell fractionation gave conflicting results with respect to the location of the chitinase activity. With the osmotic shocking method, $78 \%$ of the chitinase activity was detected in the periplasm, whereas with the spheroplast method, only $20 \%$ of the chitinase activity was detected in this fraction, most $(76 \%)$ of the activity being found in the cytoplasm (Table 2). The periplasmic fractions obtained by both methods contained only $15-20 \%$ of the cytoplasmic marker enzyme ( $\beta$-galactosidase). The relatively low level of $\beta$-galactosidase is consistent with its known cytoplasmic location, and indicates that there was no major contribution of cytoplasmic enzymes to the activities measured in the periplasmic fractions.

Since the two fractionation studies gave conflicting results, immunocytochemical analysis was conducted to 

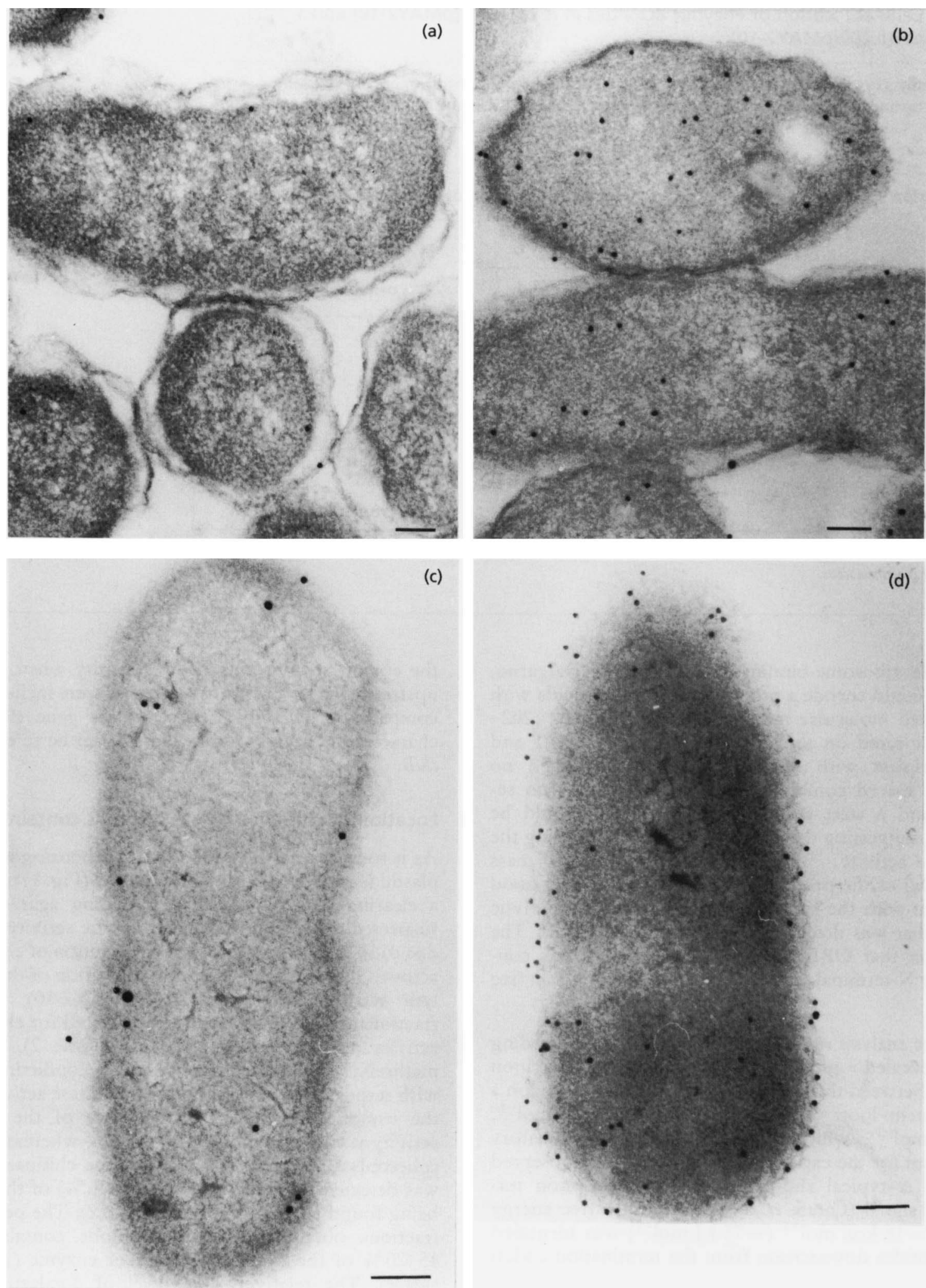

Fig. 4. Electron micrographs showing the localization of chitinase $B$ in ultrathin sections of cells. The chitinase was visualized by immunogold labelling, using polyclonal anti-ChiB antibodies. (a) E. coli DH1(pGEM-7f(+)Z3), (b) E. coli DH1(pMAY2-10), (c) S. marcescens BJL200, (d) S. marcescens BJL200(pMAY2-10). Bars, $200 \mathrm{~nm}$. 
analyse the location of the chitinase in E. coli. Immunogold-labelled electron micrographs of E. coli $\mathrm{DH} 1$ with and without pMAY2-10 (Fig. 4) clearly showed that only E. coli harbouring pMAY2-10 produced the chitinase and that the enzyme was located in the cytoplasm. This result is in agreement with fractionating studies using the spheroplast method.

\section{Location of chitinase B in S. marcescens cells overexpressing chiB}

The wild-type strain of $S$. marcescens, BJL200, produced hardly any chitinolytic activity under the non-inducing conditions used in the present study. Therefore, $S$. marcescens BJL200(pMAY2-10), which overexpressed chitinase $\mathrm{B}$ under non-inducing conditions (Table 1), was used to determine the location of chitinase $\mathrm{B}$ in $S$. marcescens. The data in Table 2 show that the chitinase was mainly found in the periplasmic fraction, independent of the fractionation method that was used. The periplasmic location of chitinase B was confirmed by immunocytochemical analysis, which showed that the enzyme was almost exclusively located in the periphery of the cells (Fig. 4).

\section{$\mathbf{N}$-terminal sequence determination of chitinase B}

The N-terminal part of the amino acid sequence deduced from $c h i B$ did not resemble signal peptides usually observed in exported prokaryotic proteins (von Heijne \& Abrahamsén, 1989). To examine whether the chitinase was processed in its $\mathrm{N}$-terminal region, as reported for the majority of proteins that are translocated across the cytoplasmic membrane, the $\mathrm{N}$-terminus of the protein purified from the periplasmic fraction of $S$. marcescens BJL200(pMAY2-10) was sequenced. The sequence of the first 14 amino acid residues at the $\mathrm{N}$-terminus was determined to be Ser-Thr-Arg-Lys-Ala-Val-Ile-Gly-TyrTyr-Phe-Ile-Pro-Thr, which corresponds to amino acids $2-15$ encoded by $c h i B$. This shows that chitinase $B$ is not $\mathrm{N}$-terminally processed during export, except for the removal of the $\mathrm{N}$-terminal methionine residue.

\section{DISCUSSION}

In the present study we identified and sequenced a gene encoding a chitinase from $S$. marcescens BJL200. The chitinase coding region identified in the cloned $S$. marcescens DNA is composed of 1497 bp coding 499 amino acids, which corresponds to a protein of $55469 \mathrm{Da}$. The data obtained from amino acid and nucleotide sequence comparison revealed that this gene is the equivalent of chiB isolated from strain QMB1466 of $S$. marcescens (Harpster \& Dunsmuir, 1989). The nucleotide substitutions (Fig. 3) within the coding region of the $c h i B$ genes from the two strains are mostly synonymous. All nonsynonymous substitutions occurred in residues that do not seem to be conserved among chitinases (results not shown; Butler et al., 1991; Kuranda \& Robbins, 1991; Watanabe et al., 1992). The chiB gene is preceded by a typical prokaryotic promoter and followed by a strong terminator. Therefore it is most likely that $c h i B$ is expressed via a monocistronic transcript and not together with other chitinase genes. One might speculate about the function, if any, of ORF2 on the antisense strand. The phenomenon of a long open reading frame on the antisense strand has been shown earlier for nylondegrading enzymes and has been suggested to be a mechanism for the evolution of new enzymes (Yomo et al., 1992).

S. marcescens cells harbouring pMAY2-10 exported most of the produced chitinase to the periplasm, as shown by fractionation and immunocytochemical studies (Table 2, Fig. 4). The location of the chitinase $B$ in the periplasm of S. marcescens suggests that the targets of the enzyme in vivo are soluble oligosaccharides capable of entering the periplasm through specific or non-specific porins in the outer membrane. Porins have solute exclusion limits around $600 \mathrm{Da}$ (Weiss et al., 1991), indicating that GlcNAc trimers (mol. mass 627) could be the substrate for the chitinase $\mathrm{B}$. We are presently characterizing the enzymic activity of the chitinase $B$; preliminary results indicate that it is a chitobiosidase that releases GlcNAc dimers from the non-reducing end of chitin chains including (GlcNAc) $)_{3-6}$ (Brurberg et al., 1994).

The comparison of fractionation experiments with immunocytochemical analyses in the present study shows that the results of fractionation experiments can be misleading. Osmotic shocking of E. coli resulted in the erroneous conclusion that considerable export of the chitinase to the periplasm occurred. Our observations corroborate earlier studies that the osmotic shocking method can produce artefacts in E. coli (Tommassen $e$ al., 1985; Díaz et al., 1989).

$\mathrm{N}$-terminal amino acid sequence analysis of the purified chitinase from $S$. marcescens BJL200(pMAY2-10) showed that it is not subject to $\mathrm{N}$-terminal processing during translocation to the periplasm. This contradicts an earlier report in which, on the basis of sequence analysis only, it was suggested that chitinase $B$ possesses a 41 amino acid signal peptide (Harpster \& Dunsmuir, 1989). The Nterminal methionine of the chitinase is probably removed by the action of methionyl-aminopeptidase, which has a preference for proteins with a small side chain in the penultimate position (Bem-Bassat et al., 1987; Hirel et al., 1989). The present results show that chitinase B of $S$. marcescens BJL200(pMAY2-10) must be exported by a secretion mechanism that differs from the general, signalpeptide-based secretion mechanism observed in prokaryotes. In $E$. coli the machinery for this secretion mechanism is either absent or non-functional for the $S$. marcescens chitinase $\mathrm{B}$.

Previously, two $S$. marcescens proteins without identifiable signal peptides, a metalloprotease (Nakahama et al., 1986) and a lipase (Akatsuka et al., 1994), have been shown to be secreted to the culture medium without processing. As for chitinase $B$, these two proteins were not secreted from $E$. coli when their respective genes were introduced into this organism. However, the metalloprotease was secreted from E. coli in the presence of Erwinia chrysanthemi protease 
secretion apparatus (Létoffé et al., 1991) and E. coli $\alpha$ haemolysin secretion functions (Suh \& Benedik, 1992). The metalloprotease of $S$. marcescens is therefore considered to belong to a group of proteins, characterized by the $\alpha$-haemolysin found in haemolytic E. coli strains, for which secretion appears to be independent of the general protein secretion pathway. The secretion apparatus for this group of proteins consists of two inner-membrane proteins and one outer-membrane protein, which direct the protein across both cell membranes, without stopping in the periplasm (reviewed by Lory, 1992; Wandersman, 1992; Pugsley, 1993). The presence of a similar secretion apparatus in $S$. marcescens has, so far, only been suggested (Létoffé et al., 1991; Suh \& Benedik, 1992).

Unlike the proteins shown to be translocated via a haemolysin-like mechanism, the chitinase of $S$. marcescens BJL200(pMAY2-10) is only exported to the periplasm and not secreted to the medium. Nevertheless, the possibility that the chitinase is exported by a haemolysinlike mechanism should be considered, since the mechanism has been shown to function for at least one secreted unprocessed $S$. marcescens protein (Létoffé et al., 1991), and since the precise character of the haemolysin-like export machinery and its functional limitations are unknown. It has been shown that the secretion of a protein via a haemolysin-like mechanism is dependent on signals present in the 50 C-terminal residues (Stanley et al., 1991; Létoffé et al., 1991; Kenny et al., 1992; Zhang et al., 1993). Several authors have suggested common characteristics for these 50 -residue $\mathrm{C}$-terminal stretches that could direct secretion, such as the presence of an amphiphatic helix (Stanley et al., 1991), a so-called aspartate-box (a stretch of small residues surrounded by a few aspartic or glutamic acid residues; Kenny et al., 1992), a helix-turn-helixstrand-loop-strand motif (Zhang et al., 1993), and a (Glu/Asp)-(X) ${ }^{11}$-Asp-(X) ${ }^{3 / 5}$-(Glu/Asp)-(X) ${ }^{14}$-Asp motif (Sěbo \& Ladant, 1993). Site-directed mutagenesis studies have indicated that negatively charged residues could be important (Stanley et al., 1991; Kenny et al., 1992). A feature seen in most proteins secreted by a haemolysinlike mechanism is the presence of repeats of the sequence GGXGXD that are involved in calcium binding (Ludwig et al., 1988; Akatsuka et al., 1994). The relevance of these repeats for export is, however, unknown.

The chitinase described in the present study does not contain any of the characteristics described or suggested for proteins exported via a haemolysin-like mechanism. This, together with the fact that the chitinase is directed to the periplasm instead of being secreted, suggests that export of this protein in $S$. marcescens involves a new, unknown mechanism for protein translocation.

\section{ACKNOWLEDGEMENTS}

Thanks are due to L. Sundheim (Norwegian Plant Protection Institute) for the generous gift of pLES3, to K. Sletten (University of Oslo) for amino acid sequence determination, and to the Electron Microscopy Section of the Biology Department of the University of Groningen. This work was supported by a grant from the Norwegian Research Council.

\section{REFERENCES}

Akatsuka, H., Kawai, E., Omori, K., Komatsubara, S., Shibatani, T. \& Tosa, T. (1994). The lip $A$ gene of Serratia marcescens which encodes an extracellular lipase having no $\mathrm{N}$-terminal signal peptide. $J$ Bacteriol 176, 1949-1956.

Bem-Bassat, A., Bauer, K., Chang, S.-Y., Myambo, K., Boosman, A. \& Chang, S. (1987). Processing of the initiation methionine from proteins: properties of the Escherichia coli methionine aminopeptidase and its gene structure. $J$ Bacteriol 169, 751-757.

Bradford, M. M. (1976). A rapid and sensitive method for the quantitation of protein utilizing the principle of protein-dye binding. Anal Biochem 72, 248-254.

Brurberg, M. B., Eijsink, V. G. H. \& Nes, I. F. (1994). Chitinases CbiA and ChiB from Serratia marcescens BJL200. M. B. Brurberg. Dr scient thesis 1994:17, Agricultural University of Norway, As, Norway.

Butler, A. R., O'Donnell, R. W., Martin, V. J., Gooday, G. W. \& Stark, M. J. R. (1991). Kluyveromyces lactis toxin has an essential chitinase activity. Eur J Biochem 199, 483-488.

Carafa, Y. A., Brody, E. \& Thermes, C. (1990). Prediction of thoindependent Escherichia coli transcription terminators. $J$ Mol Biol 216, 835-858.

Dlaz, E., Garcla, E., Ascaso, C., Ménez, E., López, R. \& Garcla, J. (1989). Subcellular localization of the major pneumococcal autolysin: a peculiar mechanism of secretion in Escherichia coli. $J$ Biol Chem 264, 1238-1244.

Dower, W. J., Miller, J. F. \& Ragsdale, C. W. (1988). High efficiency transformation of $E$. coli by high voltage electroporation. Nucleic Acids Res 16, 6127-6145.

Fuchs, R. L., McPherson, S. A. \& Drahos, D. J. (1986). Cloning of a Serratia marcescens gene encoding chitinase. Appl Environ Microbiol 51, 504-509.

Gooday, G. W. (1990). Physiology of microbial degradation of chitin and chitosan. Biodegradation 1, 177-190.

van de Guchte, M., Kodde, J., van der Vossen, J. M. B. M., Kok, J. \& Venema, G. (1990). Heterologous expression in Lactococcus lactis subsp. lactis: synthesis, secretion and processing of the Bacillus subtilis neutral protease. Appl Environ Microbiol 56, 2606-2611.

Hanahan, D. (1983). Studies on transformation of Escherichia coli with plasmids. J Mol Biol 166, 557-580.

Haandrikman, A. J., Kok, J. \& Venema, G. (1991). The lactococcal proteinase-maturation protein PrtM is a lipoprotein. J Bacteriol 173, 4517-4525.

Harpster, M. H. \& Dunsmuir, P. (1989). Nucleotide sequence of the chitinase B gene of $S$. marcescens QMB1466. Nucleic Acids Res 17, 5395.

von Heijne, G. \& Abrahamsén, L. (1989). Species-specific variation in signal peptide design. FEBS Lett 244, 439-446.

Hirel, P.-H., Schmitter, J.-M., Dessen, P., Fayat, G. \& Blanquet, S. (1989). Extent of $\mathrm{N}$-terminal methionine excision from Escherichia coli proteins is governed by the side-chain length of the penultimate amino acid. Proc Natl Acad Sci US A 86, 8247-8251.

Jones, J. D. G., Grady, K. L., Suslow, T. V. \& Bedbrook, J. R. (1986). Isolation and characterization of genes encoding two chitinase enzymes from Serratia marcescens. EMBO J 5, 467-473.

Kenny, B., Taylor, S. \& Holland, I. B. (1992). Identification of individual amino acids required for secretion within the hemolysin (HlyA) C-terminal region. Mol Microbiol 6, 1477-1489.

Kless, H., Sitrit, Y., Chet, H. \& Oppenheim, A. B. (1989). Cloning of the gene coding for the chitobiase of Serratia marcescens. Mol \& Gen Genet 217, 471-473. 
Koshland, D. \& Botstein, D. (1980). Secretion of $\beta$-lactamase requires the carboxy end of the protein. Cell 20, 749-760.

Kuranda, M. J. \& Robbins, P. W. (1987). Cloning and heterologous expression of glycosidase genes from Saccharomyces cerevisiae. Proc Natl Acad Sci US A 84, 2585-2589.

Kuranda, M. J. \& Robbins, P. W. (1991). Chitinase is required for cell separation during growth of Saccharomyces cerevisiae. J Biol Chem 266, 19758-19767.

Laemmli, U. K. (1970). Cleavage of structural proteins during the assembly of the head of bacteriophage T4. Nature 227, 680-685.

Létoffé, S., Delepelaire, P. \& Wandersman, C. (1991). Cloning and expression in Escherichia coli of the Serratia marcescens metalloprotease gene: secretion of the protease from Eschericbia coli in the presence of the Erwinia chrysantbemi protease secretion functions. $J$ Bacteriol 173, 2160-2166.

Lory, S. (1992). Determinants of extracellular protein secretion in Gram-negative bacteria. J Bacteriol 174, 3423-3428.

Ludwig, A., Jarchau, T., Benz, R. \& Goebel, W. (1988). The repeat domain of Escherichia coli hemolysin (hlyA) is responsible for its $\mathrm{Ca}^{2+}$-dependent binding to erythrocytes. Mol \& Gen Genet 214, 553-561.

Manoil, C. \& Beckwith, J. (1986). A genetic approach to analyzing membrane protein topology. Science 233, 1403-1408.

Miller, J. H. (1972). Experiments in Molecular Genetics. Cold Spring Harbor, NY: Cold Spring Harbor Laboratory.

Monreal, J. \& Reese, E. (1969). The chitinase of Serratia marcescens. Can J Microbiol 15, 689-696.

Nakahama, K., Yoshimura, K., Marumoto, R., Kikuchi, M., Lee, I. S., Hase, T. \& Matsubara, H. (1986). Cloning and sequencing of Serratia protease gene. Nucleic Acids Res 14, 5843-5855.

Oliver, D. B. (1987). Periplasm and protein secretion. In Eschericbia coli and Salmonella typhimurium-Cellular and Molecular Biology, pp. 56-69. Edited by F. C. Neidhardt and others. Washington, DC: American Society for Microbiology.

Pearson, W. R. \& Lipman, D. J. (1988). Improved tools for biological sequence comparison. Proc Natl Acad Sci USA 85, 2444-2448.

Pugsley, A. P. (1993). The complete general secretory pathway in Gram-negative bacteria. Microbiol Rev 57, 50-108.

Roberts, R. L. \& Cabib, E. (1982). Serratia marcescens chitinase: onestep purification and use for the determination of chitin. Anal Biochem 127, 402-412.

Sambrook, J., Fritsch, E. F. \& Maniatis, T. (1989). Molecular Cloning: a Laboratory Manual, 2nd edn. Cold Spring Harbor, NY: Cold Spring Harbor Laboratory.

Sanger, F., Nicklen, S. \& Coulson, A. R. (1977). DNA sequencing with chain-terminating inhibitors. Proc Natl Acad Sci US A 74, 5463-5467.

Schickler, H., Haran, S., Oppenheim, A. B. \& Chet, I. (1993). Cloned chitinases and their role in biological control of plant pathogenic fungi. In Chitin Enzymology, pp. 375-382. Edited by R. A. A. Muzzarelli. Ancona, Italy: European Chitin Society.
Sebo, P. \& Ladant, D. (1993). Repeat sequences in the Bordetella pertussis adenylate cyclase toxin can be recognized as alternative carboxyproximal secretion signals by the Escherichia coli $\alpha$-hemolysin translocator. Mol Microbiol 9, 999-1009.

Shine, J. \& Dalgarno, L. (1974). The 3'-terminal sequence of Escherichia coli $16 \mathrm{~S}$ ribosomal RNA : complementarity to nonsense triplets and ribosome binding sites. Proc Natl Acad Sci US A 71, 1342-1346.

Stanley, P., Koronakis, V. \& Hughes, C. (1991). Mutational analysis supports a role for multiple structural features in the C-terminal secretion signal of Escherichia coli hemolysin. Mol Microbiol 5, 2391-2403.

Suh, Y. \& Benedik, M. J. (1992). Production of active Serratia marcescens metalloprotease from Escherichia coli by $\alpha$-hemolysin HlyB and HlyD. J Bacteriol 174, 2361-2366.

Sundheim, L., Poplawsky, A. R. \& Ellingboe, A. H. (1988). Molecular cloning of two chitinase genes from Serratia marcescens and their expression in Pseudomonas species. Physiol Mol Plant Pathol 33, 483-491.

Tommassen, J., Leunissen, J., van Damme-Jongsten, M. \& Overduin, P. (1985). Failure of E. coli K-12 to transport PhoE-LacZ hybrid proteins out of the cytoplasm. EMBO J 4, 1041-1047.

Tronsmo, A. \& Harman, G. E. (1993). Detection and quantification of $N$-acetyl- $\beta$-D-glucosaminidase, chitobiosidase and endochitinase in solutions and on gels. Anal Biochem 208, 74-79.

Trudel, J. \& Asselin, A. (1989). Detection of chitinase activity after polyacrylamide gel electrophoresis. Anal Biochem 178, 362-366.

Vessey, J. C. \& Pegg, G. F. (1973). Autolysis and chitinase production in cultures of Verticillium albo-atrum. Trans Br Mycol Soc 60, 133-143.

Wandersman, C. (1992). Secretion across the bacterial outer membrane. Trends Genet 8, 317-322.

Watanabe, T., Oyanagi, W., Suzuki, K., Ohnishi, K. \& Tanaka, K. (1992). Structure of the gene encoding chitinase D of Bacillus circulans WL-12 and possible homology of the enzyme to other procaryotic chitinases and class III plant chitinases. J Bacteriol 174, 408-414.

Weiss, M. S., Abele, U., Weckesser, J., Welte, W., Schiltz, E. \& Schulz, G. E. (1991). Molecular architecture and electrostatic properties of a bacterial porin. Science 254, 1627-1630.

Yanisch-Perron, C., Vieira, J. \& Messing, J. (1985). Improved M13 phage cloning vectors and host strains: nucleotide sequence of M13mp18 and pUC19 vectors. Gene 33, 103-119.

Yomo, T., Urabe, I. \& Okada, H. (1992). No stop codons in the antisense strands of the genes for the nylon oligomer degradation. Proc Natl Acad Sci US A 89, 3780-3784.

Zhang, F., Greig, D. I. \& Ling, V. (1993). Functional replacement of the hemolysin. A transport signal by a different primary sequence. Proc Natl Acad Sci US A 90, 4211-4215.

Received 21 June 1994; revised 2 September 1994; accepted 21 September 1994. 